\title{
GEOMORPHOLOGICAL RESEARCHES ON THE NORTH TANGENT ARCHAEOLOGICAL SITE IN SOFIA, BULGARIA
}

DOI: http://dx.doi.org/10.18509/GBP.2016.06

UDC: 551.4:902.2(497.2)

\author{
PhD Sonya Stoyanova ${ }^{1}$ \\ Ass. Prof. Diana Dimitrova ${ }^{2}$ \\ ${ }^{1}$ Sofia University "St. Kliment Ohridski”, Department of "Climatology, Hydrology and \\ Geomorphology", Bulgaria \\ ${ }^{2}$ National Institute of Archaeology with Museum at the Bulgarian Academy of Sciences, \\ Bulgaria
}

\begin{abstract}
The archaeological site is located in the northeastern part of the Sofia kettle, Southwestern Bulgaria. There were found two archaeological structures during the construction of site № 3 along the North Tangent in Sofia. The conducted studies showed that the cultural layers are in the alluvial deposits of Perlovska river (a left tributary of Iskar river). This gave a reason for performing complex descriptions, sampling and analysis on field. There were made archaeological excavations in an area of $160 \mathrm{~m}$ length and a width of $22 \mathrm{~m}$. Geomorphological observations are marked in five key points. The samples were processed in a sedimentological laboratory and put through morphoscopic and grain-size analysis.
\end{abstract}

Keywords: archaeological structures, Sofia kettle, geomorphological researches, sedimentological analysis, facial environments.

\section{INTRUDUCTION}

The study area is located in 120-150 cm depth of present topographic surface near the Perlovska river bed.

\section{Archaeological data}

The archaeological site 3A is part of larger site № 3 in the route between $8+400 \mathrm{~km}$ to 9+ $030 \mathrm{~km}$ (Fig. 1), which is conditionally numbered with the letter "A". In the section between $8+\mathrm{km} 400$ to $\mathrm{km} 8+560$ boreholes were made with a width of $1 \mathrm{~m}$, total length of $430 \mathrm{~m}$ and a depth from $0,90 \mathrm{~m}$ to $1,20 \mathrm{~m}$. By means of the boreholes there are registered two archaeological structures. One of them is a platform with 5 clay pots placed on it, which are made of rough clay with impurities. Three of them are cups with two handles and two are pots (Fig. 2a). There is no signs of pit. It is possible it was destroyed with the removal of the humus layer. The morphology of the pottery, the texture and the clay color, the impurities, the method of firing, they clearly prove that the pottery belong to the cultural layer of the final phase of the Early Bronze Age. 


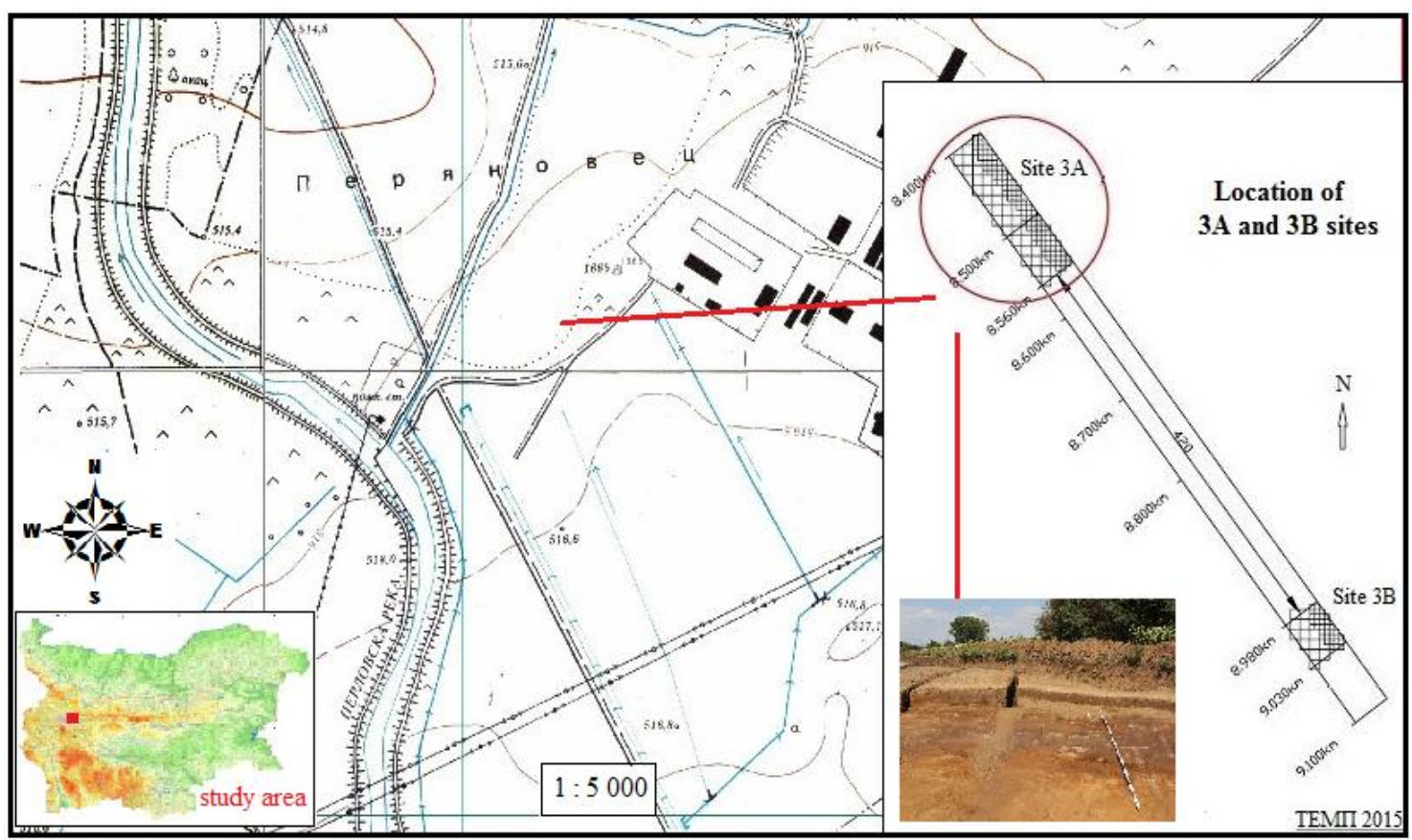

Figure 1. Location of the study area

(Source: topographic map www.cadastre.bg, geodetic map ТЕМП 2015)

The second structure is a crowding of pottery fragments (Fig. 2b). They are made by hand and refer to the same chronological period.

On hand it was studied the area between $8+460 \mathrm{~km} 8+480 \mathrm{~km}$ (Fig. 1). Here is described a horizon from sand with rusty brown color. It contrasts sharply with the surrounding horizons. In the sand were found single fragments of various pottery with highly polished edges from the Roman era and Late Antiquity. Such smoothing is only possible at relatively long (over $5 \mathrm{~km}$ ) transporting in aquatic environment which is caused the roundness of the edges. During field descriptions and sampling (September 2015) groundwater was discovered at a depth of 0,70-0,90 m.

After researching and documenting the structures, it was reached sterile soil, gravel and sand everywhere in the $3 \mathrm{~A}$ site.
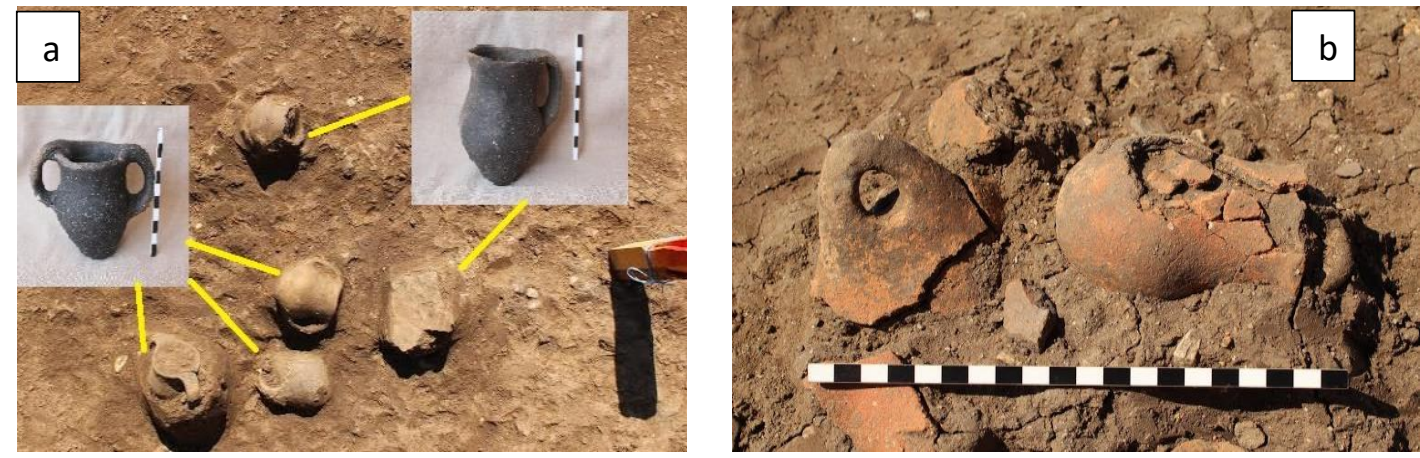

Figure 2. Ceramics from the first (a) and the second (b) archaeological structures

\section{Geological characteristic of the area}

The archaeological site is located in the eastern part of Sofia kettle morphological structure, which in tectonic terms graben and it is filled with Neogene and Quaternary sediments. The sinking part (represented by the kettle level) has contributed the lake and 
river sedimentation and the rising part (between hillsides of Stara planina/ Old Mountain and Sredna gora/ Middle forest Mountain) - active denudation and rapid weathering of bedrock.

Pliocene deposits in the archaeological site are overlapped by quaternary alluvial deposits of the Iskar river and its left tributary Perlovska. They are represented by river sediments and those on floodplain terraces (pebbles, sand, clay). The thickness of the alluvial deposits increases towards the Iskar river and in the area of excavation it varies between 70-85 m.

\section{Morphohydrographic characteristic}

Perlovska river flows round $200 \mathrm{~m}$ western and to the east our study area is bordered by ploughland, in which has a mound (526 m a.s.1.). The altitude is between $460 \mathrm{~m}$ in the midstream of Perlovska river and to the east it reaches $535 \mathrm{~m}$. It decreases from east to west - to the mainstream of Perlovska, and from south to north - along the river. The terrain is flat and it is characterized by low values of vertical and horizontal segmentation. The average slopes of the topographic surface are hesitant in narrow range - between 0 and $12^{0}$. Horizontal surfaces with $0^{0}$ are registered along Perlovska valley. Relatively equal parts of the floodplain terraces have slopes between 0 and $2^{0}$. The values of this index are increased to the east (to the mound) - between 5 and $12^{0}$ slope.

The hypsometric data and those for the vertical and horizontal segmentation show relative symmetry of the relief, which is slightly impaired to the east. As a result of the flat nature of the terrain, it became clear that the predominating slopes are between 0 and $2^{0}$. These surface indicators contribute the accumulative processes and soil formation.

In regard to hydrographic feature Perlovska basin is a part of Iskar catchment as its left tributary. The river begins from the southern slopes of Vitosha Mountain ( $820 \mathrm{~m}$ a.s.1.). It flows to north-northeast and empties into the left of the Iskar river (513 $\mathrm{m}$ a.s.1.). From the springs to the mouth Perlovska has length of $31 \mathrm{~km}$.

Therefore, the morphohydrographic characterization shows that this is an area with very low slopes, where the accumulative processes and soil formation are dominated. These slopes are a precondition for meandering and furcation of the mainstream and formation of swamping - something which can be seen from the topographic maps (1: 25 000, 1: 50 000) and Earth Google.

\section{Geomorphological and sedimentological results}

Geomorphological and sedimentological researches are consistent with the archaeological. A profile is characterized, which is conditionally called "Profile $3 \mathrm{~A}$ ". It is composed of sediments that form horizons without cultural layers. Four horizons are described in this profile. Analyses were made of the deposits that formed the horizons morphoscopic (Table 1) and grain-size (Fig. 3) analysis.

The morphoscopic analysis (Table 1) shows similar composition of the course material in horizons with the petrographic province of Perlovska river that springs from Vitosha (gneiss, quartz, andesite, granitoids). High roundness of gravel and pebbles associated with traveled distance along the river. The found ceramic fragments have the same roundness. Axis "a" of the course material (in horizon 170-200 $\downarrow \mathrm{cm}$ ) shows the movement of the mainstream to the north. This was also observed in the contemporary mainstream of Perlovska. 
Table 1.Morphoscopic analysis of the course material in Profile

\begin{tabular}{lcccc}
\hline Horizon & $\mathbf{0 - 4 0} \mathbf{~ c m}$ & $\mathbf{4 0 - 1 1 0} \mathbf{~ c m}$ & $\mathbf{1 1 0 - 1 7 0} \mathbf{~ c m}$ & $\mathbf{1 7 0 - 2 0 0} \mathbf{~ c m}$ \\
\hline Count & 10 & 9 & 5 & 30 \\
Min $(\mathbf{m m})$ & $\mathrm{a}-15 ; \mathrm{b}-12 ; \mathrm{c}-6$ & $\mathrm{a}-14 ; \mathrm{b}-10 ; \mathrm{c}-4$ & $\mathrm{a}-15 ; \mathrm{b}-13 ; \mathrm{c}-9$ & $\mathrm{a}-11 ; \mathrm{b}-6 ; \mathrm{c}-3$ \\
Max (mm) & $\mathrm{a}-46 ; \mathrm{b}-40 ; \mathrm{c}-23$ & $\mathrm{a}-43 ; \mathrm{b}-24 ; \mathrm{c}-21$ & $\mathrm{a}-29 ; \mathrm{b}-22 ; \mathrm{c}-14$ & $\mathrm{a}-86 ; \mathrm{b}-54 ; \mathrm{c}-34$ \\
Average (mm) & $\mathrm{a}-28 ; \mathrm{b}-19 ; \mathrm{c}-13$ & $\mathrm{a}-26 ; \mathrm{b}-17 ; \mathrm{c}-12$ & $\mathrm{a}-20 ; \mathrm{b}-16 ; \mathrm{c}-12$ & $\mathrm{a}-46 ; \mathrm{b}-31 ; \mathrm{c}-21$ \\
Petrography sort & gneiss & gneiss & gneiss & gneiss \\
Mean roundness & 3,8 & 2,9 & 3 & 3,4 \\
Broken pebbles \% & 40 & 0 & 0 & 27 \\
Saltation \% & 50 & 56 & 60 & 53 \\
Dragging \% & 50 & 44 & 40 & 47 \\
\hline
\end{tabular}

According to grain-size analysis (Fig. 3) the first two horizon $(0-40 \mathrm{~cm}$ and $40-110 \mathrm{~cm})$ are formed by sand and clay. The difference between them is about the size and roundness of the course material. About $70 \%$ of the sample, which is taken from horizon 110-170 $\mathrm{cm}$, is clay. The lower horizon (170-200 $\downarrow \mathrm{cm})$ is composed of sand, with inclusions of coarse gravel and small boulders.

The results of grain-size analysis indicate the transfer of two facial environments in depth. Horizon 170-200 $\downarrow \mathrm{cm}$ characterized a river facies. It has been a relatively calm situation during the formation of the upper horizon 110-170 cm. We think this horizon marks a riverside swamping and subsequently forming of floodplain terrace. From the presented data, we concluded that Perlovska permanently shifted its river bed to the west, where is its present mainstream (Fig. 4).

The investigations of alluvial deposits in points 3A-1, 2, 3, 4 (Fig. 4, cross section) show that river beds have been several or branches of the same river. To the west, from Profile $3 \mathrm{~A}$ to a distance of $13,3 \mathrm{~m}$ we observed the same deposits, which are described in the horizon 170-200 $\downarrow \mathrm{cm}$. From $13,3 \mathrm{~m}$ to $15,4 \mathrm{~m}$ there is a transitional strip with another river bed. Point 3A-1 indicates deposits from the second presumptive river bed. The grainsize analysis of 3A-1 sample showed a predominance of sand fraction (70\%), which is well washed and sorted. The transience in this strip is expressed mostly in the deposits color - alternating dark orange and black stripes.

To the west again, it is observed a sand area with alternating and interweaving of orange, reddish, whitish and black stripes. Three samples were taken from 3A-2, 3, 4 which show almost identical grain-size of the deposits, with predominating sand fraction. Again, difference is in the deposits color. We assume that the area between 15,4 $\mathrm{m}$ and $21,3 \mathrm{~m}$ is a sand island in the middle of mainstream or between two branches of the same river. This area is relatively higher than the river bed and there are found the bestpreserved ceramic pottery (Fig. 2). Probably, this island has been periodically flooded and dried. The sediments have been under conditions of oxygen regime (orange sand) during freshet and at the low water level the river has been meandering and formed swamping (black sand and organic material). Then, the regime has changed dramatically, because of some places there is a geochemical barrier (red sand) with the upper horizon. Therefore, the river facial environment has become a floodplain and dark clay horizons have overlapped. As a result, we observe another river shift to the west. Subsequently, it has formed a floodplain terrace onto the island from the temporary flooding. These facial conditions on the terrace have caused accumulation of organic material and humus. 


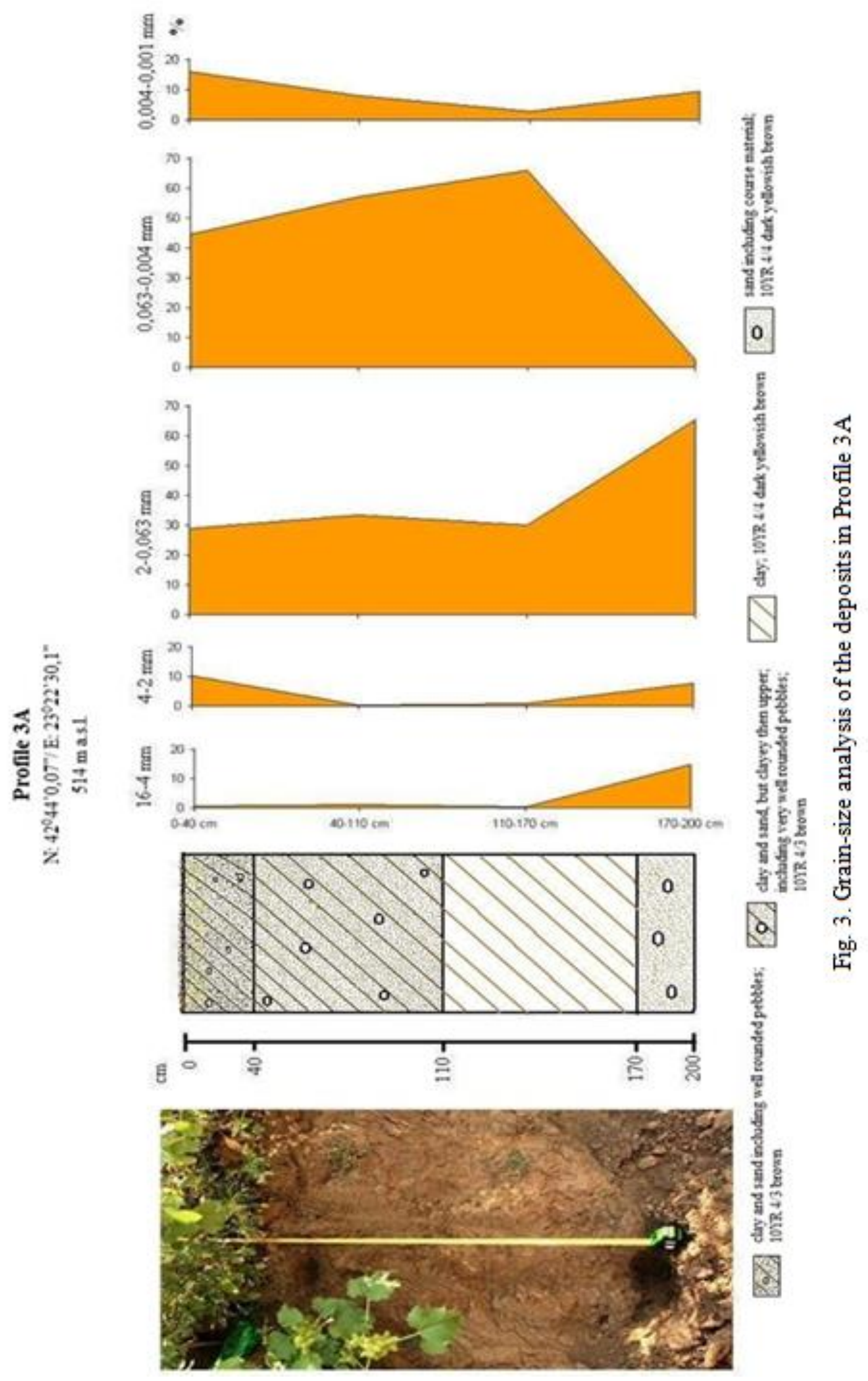




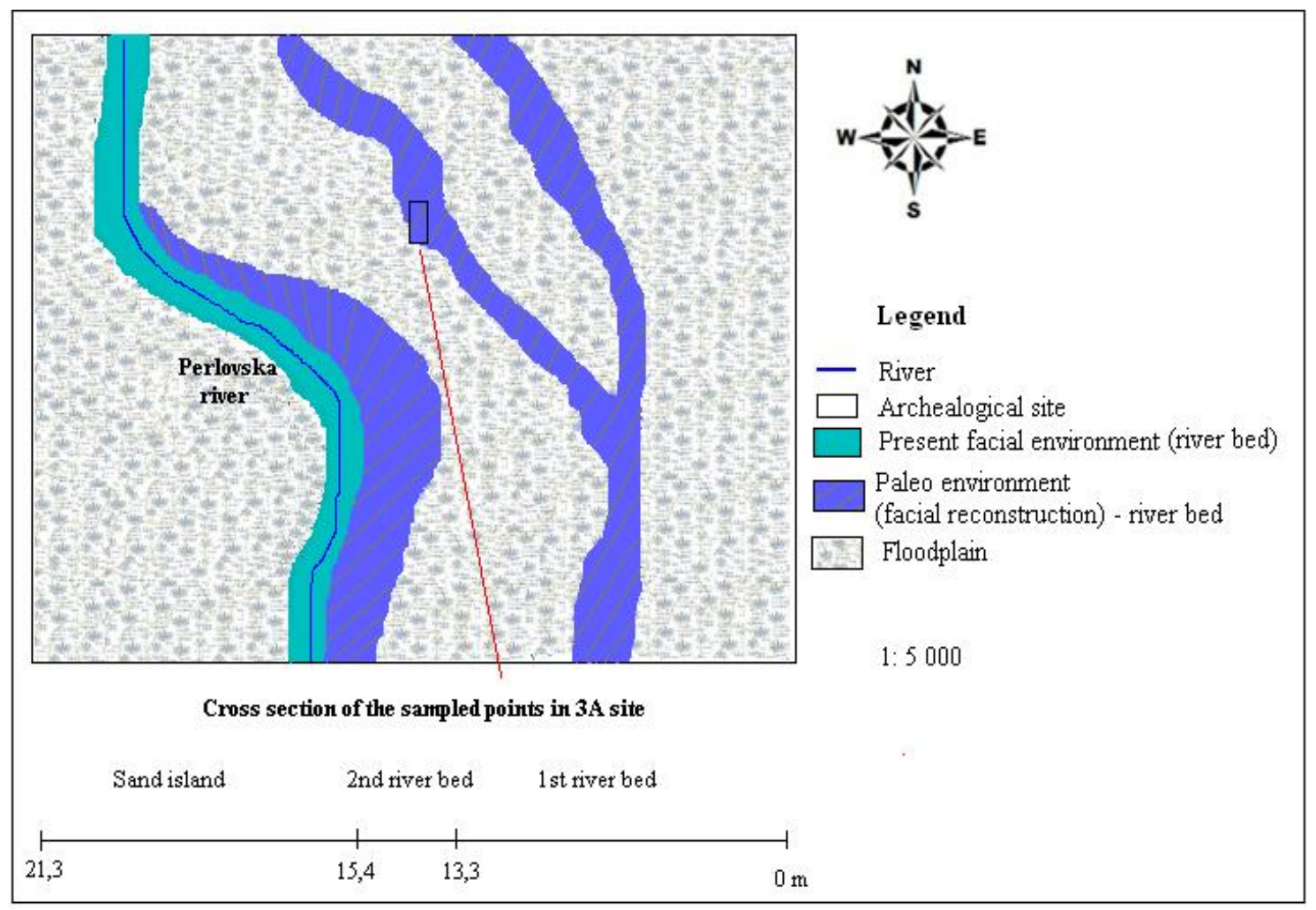

Figure 4. Paleoreconstruction by results of sedimentological analysis and map materials

\section{CONCLUSION}

The data obtained from sedimentological analysis confirmed that alluvial sediments are characterized by two facies: river and floodplain. Distribution of sand and clay, as well as the characterization of course material attest to that. The top parts of the profiles characterize contemporary soil formation on alluvial deposits.

The present location of Perlovska river bed shows migration from east to west. This was confirmed in a report with available cartographic materials, as well as the analysis of the deposits, which allowed us to recreate the paleoenvironments.

In a conclusion, the dynamics of river bed processes and their replacement with floodplain environment are clearly reflected into the alluvial deposits, as a result of the hydroclimatic conditions in the watershed of Perlovska river. The results of geomorphological studies give us reason to assume the North Tangent archaeological site (3A) is located on the old Perlovska river bed, which actually is transported the ceramic fragments from other place. 


\section{REFERENCES}

[1] Berov, B., Frangov, G., Engineering geological and geodynamic model of Sofia graben - XVI Congress CBGA, Vienna, Austria, 1998

[2] Ivanov, P., Frangov, G., Yaneva, M., Distribution, composition and properties of Quaternary deposits in Sofia kettle - XVI Carpatian-Balkan Geological Association, Vienna, 1998

[3] Kanev, D., Geomorphology of Bulgaria, publ. Science and Art, Sofia, Bulgaria, 1989

[4] Kanev, D., Neotectonic movements in the region of Sofia, ASU, BGGF, book 3 Geography, Sofia, Bulgaria, 1961/ 1962

[5] Kehaiova, M., Tanev, Iv., Geology map 1:200 000, map sheet Sofia with explanatory note, Sofia, Bulgaria, 1992

[6] Серебрянньій, Л. Р., Лабораторньій анализ в геоморфологии, М., Москва, Руссий, 1980

[7] http://web.uni-plovdiv.bg/vedrin/ (Topographic maps 1:50 000, map sheets SofiaNorth K-34-047-4 and Sofia-South K-34-059-2)

[8] www.cadastre.bg 